\title{
Mesopores Cellular Foam-Based Electrochemical Sensor for Sensitive Determination of Ractopamine
}

\author{
Liping $\mathrm{Xie}^{1}, \mathrm{Yu} \mathrm{Ya}^{1, *}$ and Liang $\mathrm{Wei}^{2, *}$ \\ ${ }^{1}$ Institute for Agricultural Product Quality Safety and Testing Technology, Guangxi Academy of \\ Agricultural Sciences, Nanning 530007, China \\ ${ }^{2}$ College of Chemistry and Materials Science, Guangxi Teachers Education University, Nanning \\ 530001, China \\ *E-mail: yayu1026@163.com, weil@gxtc.edu.cn
}

doi: $10.20964 / 2017.10 .34$

Received: 26 June 2017 / Accepted: 5 August 2017 / Published: 12 September 2017

\begin{abstract}
A mesopores cellular foam (MCF) modified carbon paste electrode (MCF/CPE) was designed for sensitive determination of ractopamine. The as-prepared MCF was characterized by scanning electron microscopy (SEM), transmission electron microscopy (TEM), X-ray diffraction (XRD), nitrogen adsorption-desorption isotherms and pore size distribution plots. Cyclic voltammetry (CV) and electrochemical impedance spectroscopy (EIS) were employed to demonstrate the large electrode surface and the fast electron transfer in the MCF/CPE which showed much better performance for the electrochemical oxidation of ractopamine when compared with the bare carbon paste electrode (CPE). Under optimized conditions, the oxidation peak current was proportional to the ractopamine concentration which was varied between 0.050 and $3.0 \mu \mathrm{M}$, with a detection limit (defined by a signalto-noise ratio of three) of $0.010 \mu \mathrm{M}$. The proposed sensor was applied to determine the ractopamine content in pork samples with satisfactory results.
\end{abstract}

Keywords: Mesopores cellular foam, Modified electrode, Ractopamine, Linear sweep voltammetry

\section{$\underline{\text { FULL TEXT }}$}

(C) 2017 The Authors. Published by ESG (www.electrochemsci.org). This article is an open access article distributed under the terms and conditions of the Creative Commons Attribution license (http://creativecommons.org/licenses/by/4.0/). 